\title{
Selected Reference Books of 1966-67
}

THIS ARTICLE continues the semi-annual series $^{1}$ originally edited by Constance $\mathrm{M}$. Winchell. Though it appears under a byline the list is actually a project of the reference department of the Columbia University libraries, and notes are signed with the initials of the individual staff members. ${ }^{2}$

Since the purpose of the list is to present a selection of recent scholarly and foreign works of interest to reference workers in university libraries it does not pretend to be either well-balanced or comprehensive. Code numbers (such as AD34, DB79) have been used to refer to titles in the Guide to Reference Books. ${ }^{3}$

\section{GUIDE}

Winchell, Constance Mabel. Guide to Reference Books. 8th ed. Chicago: ALA, 1967. 741p.

What a pleasure it is to note the appearance of the 8th edition of the Guide! Judicious selection, a slightly smaller type size for the entries, and a somewhat fuller page have combined to keep the nearly eight thousand items within the convenient single volume format. A new classification scheme has been developed for this edition, grouping the items in five main sections: A, General reference works; B, Humanities; C, Social sciences; D, History; and E, Pure and applied science. Each section has numerous subdivisions, and the major subsections, in turn, have their distinctive letter prefixes (e.g., $\mathrm{AA}$, Bibliography; $\mathrm{AB}, \mathrm{Li}-$ brarianship; BA, Philosophy; BB, Religion).

${ }^{1} C R L$, January and July issues starting January, 1952.

${ }^{2}$ Linda Benson, Marilyn Goldstein, Rita Keckeissen, Evelyn Lauer, Barbara Railo, Charlotte Smith.

${ }^{3}$ Constance M. Winchell, Guide to Reference Books (8th ed.; Chicago: ALA, 1967).
Most items are annotated, and the annotations meet the high standard one has come to expect in the Guide. Indexing, too, is up to expectations in its thoroughness. In short, Miss Winchell leaves the field with colors flying.-E.S.

\section{Book Selection}

Books for College Libraries. Chicago: ALA, 1967. 1056p.

Sub-title: A selected list of approximately 53,400 titles based on the initial selection made for the University of California's New Campuses Program and selected with the assistance of college teachers, librarians and other advisers. Prepared under the direction of Melvin J. Voight and Joseph H. Treyz.

This long retrospective list of monographs, intended as a new selection aid for college libraries, was compiled by specialists who chose each title on its own merits with the over-all design of building a balanced library collection to support basic undergraduate courses in all fields. Subject coverage, consequently, is wide, and both scholastic and recreational interests were considered. No imprints later than 1963 are listed and, although perhaps a third of the books are out of print, this information is not noted in the entry. No periodicals, newspapers or films are included. Arrangement is by Library of Congress classification with closely related classes grouped; within each section, entry is alphabetic by author. Complete bibliographical information plus the LC card number is given; price is omitted. There is a complete author index, and another index for major subjects.-R.K.

\section{DIRECTORY}

Little, Arthur D., Inc. Directory of Selected Research Institutes in Eastern Europe. Prep. for the National Science Foundation. New York: Columbia Univ. Pr., 1967. 445p. \$12. 
Although this directory was originally meant to cover only institutes in the areas of the biological and physical sciences, information volunteered by various East European agencies led to the inclusion of certain other fields as varied as architecture, linguistics, and social insurance. Emphasis, of course, is clearly on scientific research institutes in Bulgaria, Czechoslovakia, Hungary, Poland, Rumania, and Yugoslavia. Arrangement is by country, with the official name of the institute followed by an English translation of the name, the address, director's name, and notes on the major activities of the institute. Indexes of directors' names, names of institutes (including abbreviations), and of subjects complete the work.-E.S.

\section{ENCYCLOPEDIA}

Brockhaus Enzyklopädie in zwanzig Bänden. 17. völlig neubearb. Aufl. des Grossen Brockhaus. Wiesbaden: Brockhaus, 1966- . v.1- . DM79 per v.

Contents: v.1, A-Ate.

A change of title and expanded coverage are the features which first claim attention in the new edition of this standard work. Indeed, the twenty-volume format promises to bring the range of coverage back to that of the 15th edition (Brockhaus' Konversations-Lexikon). Spot checking of the first volume indicates that, while many of the shorter articles are unchanged from the 16th edition (published 1952-57 in 12v.; Guide AD34), some have been augmented or rewritten, and there are, of course, many new entries. Numerous long articles such as those on countries and continents evidence considerable reworking and updating. Bibliographies appear to have been given particular attention, with emphasis placed on recently published works. Color plates and maps are new, but a surprising number of the black and white illustrations are carried over from earlier editions. Good paper and sharper reproduction, however, make for a highly satisfactory appearance. The publisher estimates a total of two hundred and twenty-five thousand articles in sixteen thousand pages for the completed work.-E.S.

\section{Periodicals \& Newspapers}

Fowler, Maureen J. Guides to Scientific Periodicals; annotated bibliography. [London $_{]}$: Library Association, [1966 ${ }_{\text {] }}$. 84s.

This long list (1048 entries) is designed as an aid in selection and use of periodicals, and in identification and verification. "Guides" includes all types of publication: bibliographies, union lists, library catalogs, organization directories that list periodicals, national or other bibliographies which include periodicals as well as monographs. Consequently, "scientific" in the title is somewhat misleading, for many lists of much wider coverage are given. The specialized subject division of the first section is, of course, limited to science. Entries are grouped in three sections: universal guides, national and regional guides, and guides to periodicals of international organizations, this last a list of only six items. Full bibliographical information is given, and for the most useful items annotations are quite detailed. There is a long author-title-subject index.-R.K.

\section{Index to Commonwealth Little Magazines.} [v.1- ], 1964/65- . New York: Johnson Reprint Corp., 1966- . Biennial. (v.1, 187p. \$7.50)

\section{Stephen H. Goode, editor.}

Indexing of "little magazines" has heretofore been largely confined to those American publications covered by the now well established Index to Little Magazines (Guide AF132). Mr. Goode, who recently undertook retroactive indexing of American "littles," now promises biennial volumes of this new index devoted to "a selected list of English-language little magazines published in Commonwealth and ex-Commonwealth countries." (Pref.) Patterned after the American series, the new index covers thirty-four magazines, but unfortunately some are indexed only for 1965, and the volume numbers are not indicated in the list of periodicals indexed. The compiler plans retroactive indexing of these Commonwealth publications.-E.S.

Stanford University. Hoover Institution on War, Revolution, and Peace. Soviet and 
Russian Newspapers at the Hoover Institution, a Catalog. Comp. by Karol Maichel. [Stanford, Calif.]: 1966. 235p. $\$ 6.50$. (Hoover Institution bibliographical series, no. 24)

The purpose of this catalog is to list the holdings of one of the best collections of Russian imperial, Soviet, and emigré newspapers in the United States. According to the editor, however, only 85 per cent of the actual holdings are listed, owing to the difficulty of classifying some materials as newspapers or as journals. Borderline materials will be included in a forthcoming catalog of Russian periodicals at the Hoover Institution.

Arranged alphabetically by title (or, where several newspapers have the same title, alphabetically by place of publication) the catalog notes changes of title, misnumbering or suppression of issues, etc. A slightly confusing practice of sometimes listing holdings, sometimes only missing issues, and at other times both the available and missing issues detracts from really easy use of the volume. Wherever possible the entries include reference to additional bibliographic sources. Since two of the compendia thus referred to are Library of Congress and Columbia University library catalogs of Russian newspapers, we have here a checklist of the holdings of three major libraries for the titles mentioned.E.L.

Willing's European Press Guide. Issue 1-

1966/67- . London: Hutchinson Willing Ltd., 1966- . Annual. (v.1, 732p. \&5, 5s.)

This new annual is designed as a companion volume to Willing's Press Guide (Guide AF50), now in its $92 \mathrm{~d}$ year. The latter will continue to list newspapers and journals of the United Kingdom, Northern Ireland and the Irish Republic, and the new guide will list those of the western countries of continental Europe: Austria, Belgium, Denmark, France, Germany, Italy, Netherlands, Norway, Portugal, Sweden, and Switzerland. Following the plan of the earlier guide, material is presented in an alphabetical, classified list, with four separate language indexes providing a more specific subject breakdown. Some thirtyfour thousand newspapers and magazines are listed; information is limited to name and address, publisher, frequency, and price.-C.S.

\section{Dissertations}

Canada. Public Archives. Register of PostGraduate Dissertations in Progress in History and Related Subjects. Compiled by the Public Archives of Canada and published by the Canadian Historical Association. No.1- , 1966- . [Ottawa, 1966- j. Annual.

A classified list with an author index, the Register will be a continuation of the list of theses formerly published in the Canadian Historical Review. Included will be all theses (at both the master's and the doctoral level) which are in preparation in departments of history at Canadian universities, plus those in the departments of political science, economics, geography, etc., "if they involve some degree of historical research" (Foreword). Theses being prepared at foreign universities dealing with Canadian history, government, and politics are also included. Only works in progress are listed.-C.S.

\section{BIOGRAPHY}

Bonacker, Wilhelm. Kartenmacher aller Länder und Zeiten. Stuttgart: A. Hiersemann, 1966. 244p.

Brief biographical information on those individuals of all places and periods (including the present), who have been involved in the creation and production of maps is presented in this volume. Wherever possible, birth and death dates, locale and sphere of activities are given, and reference is made to standard biographical sources where further information may be found. Arrangement is alphabetical, and there are ample cross references from the variant spellings of many cartographers' names. The work will be useful primarily for purposes of simple identification.-E.L.

McGraw-Hill Modern Men of Science; 426 Leading Contemporary Scientists. Presented by the editors of the McGraw-Hill Encyclopedia of Science and Technology. 
New York: McGraw-Hill, [1966 . 620p. il. $\$ 19.50$.

Addressed chiefly to teachers and students of high school and college, this alphabetical directory of important scientists, the great majority of them still living, is a companion volume to the publisher's Encyclopedia of Science and Technology (Guide EA86), which excludes biographical articles. Entries average about a thousand words, and give essential biographic data and description of achievements against their scientific background. Most accounts were written by the scientists themselves; others were submitted to them for review and correction. An index of all persons and subjects referred to in the text, and a list of all the scientists arranged by field are useful reference features. Cross reference is made to Encyclopedia articles for fuller information on subjects mentioned.-R.K.

\section{PHILOSOPHY}

The Encyclopedia of Philosophy. Ed. by Paul Edwards. New York: Macmillan, [1967]. 8v. \$219.50.

Not since J. M. Baldwin's Dictionary of Psychology and Philosophy (1901; Guide BA26) has there been a major English-language reference work in the field of philosophy. This gap has now been filled by the eight-volume Encyclopedia of Philosophy. Unlike Baldwin's dictionary, the encyclopedia treats its topics at length, and emphasizes individual thinkers (to whom are devoted over nine hundred of the fifteen hundred articles). Claiming as their domain all of philosophy-Eastern and Western, ancient, medieval, and modern - and related disciplines, the editors have recruited over five hundred eminent contributors from all over the world.

Those articles not dealing with individual thinkers are concerned with controversial philosophical issues and the history of various fields of philosophical endeavor. A detailed index and copious cross references help to eliminate the duplication which necessarily results from an alphabetical arrangement, especially one which discusses the philosophy of a man in one entry and the historical significance of his theories in another. The signed articles are quite readable, intended for specialist and nonspecialist alike, and are accompanied by bibliographies of varying length. The bibliographies appended to the survey articles are especially valuable as guides to the study of the development of an issue or a subfield of philosophy.-L.B.

Koren, Henry J. Research in Philosophy; a bibliographical introduction to philosophy and a few suggestions for dissertations. Pittsburgh: Duquesne Univ. Pr. ${ }_{[} 19666_{]}$ 203p. $\$ 3.95$.

Another of the "guides to the literature," this work is intended to introduce graduate students in philosophy to the bibliographical tools and sources of their field. The classified arrangement supplemented by name and subject matter indices is characteristic of such guides, but Koren's volume has the distinction of being a pioneer work for this discipline. The choice of titles in this selective list appears at times to emphasize type rather than value, with annotations generally provided only for the outstanding tools. The general sections of the book (the introductions and definitions) seem too elementary for graduate students, but the section on bibliographical tools is quite well done. It covers forty pages, and treats bibliographies of general philosophy, related fields, branches of philosophy, trends of thought, periods, language areas, countries, and individual philosophers.-L.B.

The Philosopher's Index; an international index to philosophical periodicals. v.1, no.1- , Spring, 1967- . Bowling Green, Ohio: Bowling Green Univ., 1967- . Quarterly. \$8.50 yr.

Many of the seventy-six periodicals indexed by the Philosopher's Index are also covered by the more comprehensive Répertoire bibliographique de la philosophie (Guide BA14), but the former has the advantage of promptness: it appears quarterly rather than annually. Approximately twothirds of the titles are British and American, and French titles predominate among the remaining third, so it is not quite the international index claimed in the subtitle. Periodicals were chosen by an editorial board of six academicians acting on the recommendations of an advisory board at 
Bowling Green. The list is limited and selective, and the resulting index is not large. Produced by electronic data processing equipment, the subject index utilizes a keyword system supplemented, where necessary, by entry under a subject which is implicit in the article rather than explicit in the title. The author index is separate, but full bibliographical information is provided each time an article is cited. No mention of cumulations has been made in this first issue.-L.B.

\section{RELigion}

Bible. English. King James Version. The New Scofield Reference Bible; with introductions, annotations, subject chain references, and such word changes in the text as will help the reader. New York: Oxford University Press, 1967. 1392p., 192p. maps. $\$ 7.25$.

A revision by a group of nine scholars (with E. Schuyler English as chairman) of the Scofield Reference Bible of 1909 and 1917, this edition presents the Authorized text with certain word changes made to clarify meaning for contemporary readers. Such substitutions are shown clearly, and the King James Version word given in a note. The reference aspect of the book is enhanced by several features: indication of pronunciation of difficult proper names; index to annotations; index to the chain references which identify all biblical verses concerning a particular doctrine; and, most important, a concordance to proper names, subject and key words compiled especially for this revision.-R.K.

New Catholic Encyclopedia. Prepared by an editorial staff at the Catholic University of America. New York: McGraw-Hill, [1967], 15v. il. $\$ 500 ; \$ 450$ to libraries.

Subtitle: An international work of reference on the teachings, history, organization, and activities of the Catholic Church, and on all institutions, religions, philosophies, and scientific and cultural developments affecting the Catholic Church from its beginning to the present.

This welcome encyclopedia "proposes to meet the need for an authoritative work of reference for the English-speaking world"
(Pref.) for the fields named in the subtitle. It is not a revision of the Catholic Encyclopedia, 1907-14 (Guide BB201), but a completely new work with an impressive international roster of some forty-eight hundred contributors. Because articles deal with the life of the Church in its total environment, entries on persons, institutions, religions, philosophies, scientific developments and intellectual movements of importance enlarge the expected scope of the work.

Coverage is through the close of "Vatican II" and the work reflects the Council's ecumenical outlook and interests as well as twentieth-century advances in scholarship, particularly in scripture, liturgy, patrology, and theology. Articles are signed; most carry concise bibliographies, but for important subjects there are extended lists of references (e.g., that for St. Augustine runs to a full column). Cross references are used liberally, drawing together related materials that appear in different articles. Volume 15 contains lists of editors, consultants and contributors, lists of abbreviations, and the analytic index of three hundred and fifty thousand entries. The page is of well designed, two-column format with enough variation in typeface to make headings, subdivisions and book titles readily discernible. The wealth of well chosen and beautifully reproduced illustrations (seventy-five hundred of them) is an attractive feature. The work should be in every sizable reference collection.-R.K.

\section{LiNGUISTICS}

Dulong, Gaston. Bibliographie linguistique du Canada français. Paris: Klincksieck, 1966. 166p. \$6.

Including most of the entries from the Bibliographie du parler français au Canada of J. Geddes and A. Rivard (published 1906), this bibliographical guide expands the earlier work by updating material through 1965. The first of a planned comprehensive series on the language and literature of this region, this volume includes citations to many kinds of material to mirror the French Canadian in the light of his speech. Scope is international, and includes books, theses, manuscripts, and periodical articles. Chronologically arranged, entries 
are consecutively numbered, and most are annotated. An excellent historical summary makes up the introduction. Author and subject indexes complete this useful bibliography for linguist and historian.-M.G.

\section{LITERATURE}

Goethe-Wörterbuch. Hrsg. von der Deutschen Akademie der Wissenschaften zu Berlin, der Akademie der Wissenschaften zu Göttingen, und der Heidelberger Akademie der Wissenschaften. Stuttgart: W. Kohlhammer Verlag, 1966- . v.1, lfg.1- .\$7.25 per Lfg.

\section{Contents: Lfg.1, A-abrufen.}

From the first fascicle of this work it is already evident that it will be a contribution of enormous value to Goethe scholarship. Listing all words used by Goethe except personal names, it serves as both a dictionary and a concordance, giving definitions, etymology, and synonyms, as well as quotations from the literature to show where the words were used. Citations to scholarly works and quotations from non-Goethe literature related to the term under discussion frequently appear at the end of the articles. The editors estimate that the completed dictionary (which has been in preparation for twenty years and is almost half finished) will consist of five volumes.-E.L.

Kosch, Wilhelm. Deutsches Literatur-Lexikon. 3., völlig neu bearb. Aufl., hrsg. von Bruno Berger und Heinz Rupp. Bern: Francke, 1966- . Lfg. 1- . DM20 per Lfg.

\section{Contents: Lfg.1, Aal-Banchini-Brunner.}

When completed, the latest edition of this respected work will run to eight volumes, twice the size of the previous edition (1947-58; Guide BD576). The one-volume condensation which appeared in 1963 had eliminated entries for subjects, first lines, quotations, and place names, and the present edition continues this policy by limiting entries to the authors and anonymous works of all eras in the German-speaking area. Neo-Latin writers are included, as are literary historians, essayists, philosophers, and historians. Individual entries, however, have been expanded, and list as many re- lated primary and secondary sources as possible. Many users will undoubtedly find the elimination of entries for the categories mentioned above a loss, but the greater depth of coverage in other areas is compensation enough to continue to make this a staple reference source.-E.L.

\section{McCready, Warren T. Bibliografía temática de estudios sobre el teatro español} antiguo. Toronto: Univ. of Toronto $\mathrm{Pr}$. [1966] 445p. \$12.50.

Devoted to the Spanish theater from its inception in the Middle Ages to the end of the "golden age" (ca.1750), this subject bibliography lists books and periodical articles published from 1850 to 1950 . Over eight hundred periodicals in twelve languages were gleaned for its compilation. Mr. McCready has chosen a rather complex arrangement. The prevailing chronological arrangement is subdivided within each period into general works and works on individual authors. These sections are further subdivided by form of the study, i.e., article or book. Articles are arranged by key word subject system; books alphabetically by author's name. One wonders whether this complexity is necessary. Elaborate cross referencing and an author index should, however, add to the usability of the bibliography. The compiler has certainly endeavored to include as much information as possible: citations to reviews of books are provided, and the list of periodicals indexed is keyed to indicate the library in which the publication was consulted and the items (by number) in the bibliography which appear in the periodical.-L.B.

Stratman, Carl Joseph. Bibliography of English Printed Tragedy, 1565-1900. Carbondale: Southern Illinois Univ. Pr., 1966. 843p. \$15.

Here is a biblographical tool primarily devoted to English tragedy, covering all works whose first editions were printed between 1565 and 1900 in England, Scotland, and Ireland. (The main exclusion, understandably, is a listing of Shakespeare's tragedies, although adaptations of these plays are cited.) It may be viewed in part as a continuation of the author's Bibliography 
of Medieval Drama (Guide BD134), which has a large section devoted to England. Consecutively numbered entries are arranged alphabetically by author or anonymous title, with pagination, and any pertinent notes or comment; e.g., reference to reviews and unpublished dissertations. There are cross references, a chronological table, and a title index, plus lists of locations for collections, anthologies, and extant manuscripts. In short, this is a comprehensive work of prime value to the literary scholar and dramatic historian.-M.G.

Wright, Lyle H. American Fiction, 18761900. San Marino, Calif.: Huntington Library, 1966. 683p. $\$ 15$.

A companion to the author's previous volumes covering 1774-1850 and 1851-1875 (Guide BD246, BD247), this new work also serves as a bibliographical guide rather than a fully descriptive bibliography. The scope is similar: books for adults by American authors which were printed in the United States. Entries are arranged by author or anonymous title, and give locations among fifteen American libraries. Some citations include brief notes; titles within collections are given separately and collectively; and the title index includes these analytics. The usefulness of this work is great, though it would have been desirable that the second and third volumes in the series had chronological indexes such as is found in the 1774-1850 volume.-M.G.

\section{Social SCIENCE}

Ebony. The Negro Handbook. Chicago: Johnson Publishing Co., 1966. 535p. \$10.

Documenting the Negro's present-day status on a wide range of subjects of a sociological, political, economic, and cultural nature, this is basically a fact-book with much statistical and directory-type information. Arranged topically, the sections of the handbook contain a variety of short articles, tables (with sources indicated), chronologies, lists, and directories. Of note is the inclusion of a biographical dictionary of major contemporary personalities, and an annotated list of major works on the Negro arranged by topic. A comprehensive subject index concludes this handy sum- mary of the Negro today. It is a useful parallel and complement to The American Negro Reference Book edited by John Davis.-M.G.

International Bibliography of Studies on Alcohol. Mark Keller, ed. New Brunswick, N.J.: Rutgers Center of Alcohol Studies, 1966- .v.1-

Contents: v.1, References, 1901-1950, prep. by Sarah Spock Jordy. 631p. $\$ 40$.

Alcohol literature has always been widely scattered over various disciplines, ranging from the sociological and legal to the medical and psychological. This volume is the first of a bibliographical series which will try to gather together all pertinent material in order to facilitate research and avoid unnecessary duplication. The second volume, in preparation, will provide the author and subject indexes to this one, which is an author list arranged by year. These are to be followed by decennial supplements. Thus far the editors have relied heavily on printed and previously compiled bibliographies, making for a certain admitted overemphasis on well-documented areas. Format is clear, with the authors' names in boldface and the item numbers easily identifiable. A large amount of material has been listed here, and if the indexing is done well it should prove to be an invaluable bibliographic aid.-B.R.

\section{Atlas}

Odyssey World Atlas. New York: Odyssey Books, 1966. 317p. $42 \mathrm{~cm}$. $\$ 19.95$.

A completely new reference atlas, this volume contains 169 maps arranged to give a view of world patterns, followed by coverage of the continental areas. Except for the sections devoted to the world and to North America, "the sequence of presentation is always parallel: first a map showing physical features, then political regional maps, and finally a series of thematic maps which depict selected patterns of man and his regional setting." (Introd.) North America is covered in more detail than the other continents. New Zealand is treated as part of Oceania, with separate maps being provided for Australia, the Pacific and Indian 
Oceans, the Atlantic Ocean, and the Polar regions. Official spelling of place names is used throughout, and there is an index of one hundred and five thousand place names. While it does not contain as much gazeteer information as the Rand McNally and Hammond atlases, the maps have a higher degree of legibility. This is due to the large page size, the separation of political and relief maps, the omission of detailed road and railroad information, and to the fact that no attempt has been made to standardize the scale.-C.S.

\section{HISTORY}

American Heritage. The American Heritage Pictorial Atlas of United States History, by the editors of American Heritage. New York: American Heritage Pub. Co., 1966. il. 424 p. $\$ 16.50$.

Advertised as the first thoroughgoing American atlas since Paullin's Atlas of the Historical Geography of the United States (Guide DB79), this work is said to contain 210 newly-commissioned maps in color, 150 historical illustrations and maps, and sixty thousand words of narrative. Chronologically arranged, the maps and text trace the evolution of the North American continent from glacial times to the present, with sociological as well as historical and geographical data included.

Maps and pictures are handsomely reproduced, and the narrative is by well known writers. It is, however, a more superficial work than Paullin, the map explanations being somewhat oversimplified. Except for material on the period from World War II to present, the work contains little information that cannot be found in Paullin or in Lord's Historical Atlas of the United States (Guide DB78). Indeed, there are various omissions, such as maps showing changes of wealth distribution, growth of organized labor, and information on politics. The perspective views of famous battles and of nineteenth-century cities are more decorative than informative.-C.S.

Duignan, Peter. Handbook of American Resources for African Studies. [Stanford, Calif.]: Hoover Institution on War, Revolution, and Peace, Stanford University,
1967. 218p. (Hoover Institution bibliographical series no. 29)

Offered as a first attempt to describe American resources for African studies, this work goes well beyond the scope of Duignan and Collins' Americans in Africa (Guide DD3) which concerned itself with records and papers of Americans who visited Africa. Describing library and manuscript collections, church and missionary archives, art and ethnographic collections (and including a list of private United States collectors), and some business archives, the Handbook intends to call attention to the whole range of African resources and "to encourage utilization of the scattered but rich materials held by various American institutions and museums." (Pref.) Most of the information was derived from questionnaires, and entries vary from a few lines to several pages. There is a very extensive section on U.S. National Archives resources. Fully indexed.-E.S.

An Encyclopaedia of New Zealand. A. H. McLintock, ed. Wellington: R. E. Owen, 1966. 3v. il. \&7, 10 s.

Despite an obvious nationalism, this government sanctioned encyclopedia manages to present a many-faceted view of New Zealand. Its 359 contributors have produced eighteen hundred general articles and half as many biographies. While an alphabetical arrangement has been chosen, cross referencing, broad article headings, and an index of over twenty thousand entries help to tie together similar materials scattered throughout the volumes. The articles are very readable and are illustrated with maps, black and white photographs, line drawings, and diagrams. Bibliographies do not accompany the majority of the articles. The encyclopedia seems strongest in discussions of zoological and botanical species native to New Zealand, and in biographies. Very few living people are represented, as the editor intended the biographies to illustrate the glory and the history of New Zealand.L.B.

Muller, C. F. J. A Select Bibliography of South African History. Pretoria: Univ. of South Africa, 1966. 215p. R 3.50. 
The first attempt at a comprehensive guide for historical research on South African history, this selective bibliography cites about twenty-five hundred titles, primarily scholarly books published throughout the world, but including some periodical articles and unpublished essays and theses. There are three main sections: the first is concerned with such aids to research as bibliographies, historical atlases, and general histories; the second, arranged by period, surveys the field chronologically from the beginnings up to the present; and the third and longest part is arranged by subject, covering the humanities, social sciences, and sciences. Entries are numbered consecutively and are given by author or other main entry within sections; author and name indexes conclude the work. The value of this compilation to the scholar and historian is undeniable; it is hoped that in future, anticipated supplemental annotations might be included.-M.G.

Pennsylvania University Library. The $M a$ clure Collection of French Revolutionary Materials. Ed. by James D. Hardy, Jr., John H. Jensen, and Martin Wolfe. Philadelphia: Univ. of Pennsylvania Pr., [1966] $.456 \mathrm{p} . \$ 50$.

This catalog serves both to identify and locate items for the historian, and substitutes for conventional cataloging of this rich subject collection of primary materials at the University of Pennsylvania. The collection consists of 1,460 bound volumes containing twenty-five thousand items grouped by subject. The catalog lists and describes the volumes in numerical order. For serials, title, dates, notation of indexes, and useful descriptive annotations appear; for pamphlet volumes, author (often only a surname), full title, date, and paging are given. Indexes of authors, committees, and commissions are appended. Two interesting essays by John J. Jensen, one on French Revolution collections in the United States, the other on the Maclure collector and collection, precede the main list.-R.K.

Tauro, Alberto. Diccionario enciclopédico del Perú. [Lima] : Editorial Mejía Baca, [1967]. 3v. il. $\$ 88$.

Names and terms relating to Peruvian life, culture, and history are dealt with in this compilation. There are a great many biographical sketches (including some of living persons), numerous entries for place names, educational and cultural institutions, and extensive coverage of the flora and fauna of Peru. In addition, terms borrowed from or peculiar to the native races of the country are well represented, so that the work should prove useful to the historian and the anthropologist alike. Articles are generally brief and, unfortunately, there are no bibliographies or lists of sources.E.S. 